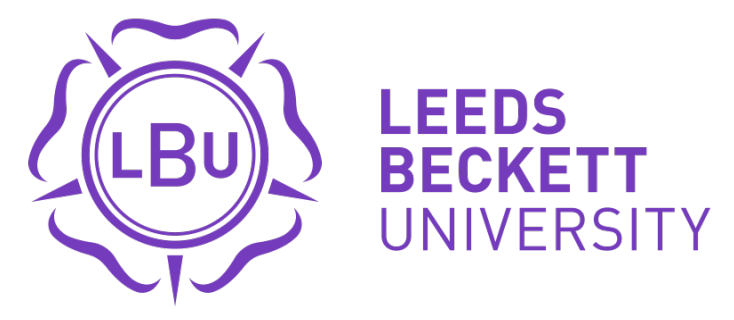

Citation:

Takriti, RA and Atkinson, SJ and Elhoweris, H (2018) Teachers' expectations of children with Down Syndrome starting school in the United Arab Emirates or United Kingdom. European Journal of Special Needs Education, 34 (4). pp. 546-554. ISSN 0885-6257 DOI: https://doi.org/10.1080/08856257.2018.1553137

Link to Leeds Beckett Repository record:

https://eprints.leedsbeckett.ac.uk/id/eprint/7187/

Document Version:

Article (Accepted Version)

This is an Accepted Manuscript of an article published by Taylor \& Francis in European Journal of Special Needs Education on 29th November 2018, available online: https://doi.org/10.1080/08856257.2018.1553137

The aim of the Leeds Beckett Repository is to provide open access to our research, as required by funder policies and permitted by publishers and copyright law.

The Leeds Beckett repository holds a wide range of publications, each of which has been checked for copyright and the relevant embargo period has been applied by the Research Services team.

We operate on a standard take-down policy. If you are the author or publisher of an output and you would like it removed from the repository, please contact us and we will investigate on a case-by-case basis.

Each thesis in the repository has been cleared where necessary by the author for third party copyright. If you would like a thesis to be removed from the repository or believe there is an issue with copyright, please contact us on openaccess@leedsbeckett.ac.uk and we will investigate on a case-by-case basis. 


\title{
Teachers' perceptions of successful transition to school for children with and without Downs Syndrome in the UAE and England.
}

Takriti, R., Atkinson, S.J. \& Elhoweris, H.

\begin{abstract}
Transition into school has been shown to correlate with later school outcomes, with those children who experience a more positive start to school having more positive outcomes throughout their school life, both academically and socially. Children with Special Educational Needs (SEN) face more challenging transitions. Teacher attitudes and expectations of children with SEN play a key role in determining the quality of the transition. Early Years Foundation Stage teachers were recruited from the UK and from the UAE to take part in this study. They completed a questionnaire twice, rating the importance of factors in ensuring a successful transition to school for children with no SEN and with Downs Syndrome. Significant differences in the rating of factors were found for the two groups of children. Between-country differences were significant for Knowledge and for Academic. The implications of differences in transition expectations cross-culturally and for the transitioning of children with SEN are discussed.
\end{abstract}

\section{Keywords}

Transitions, Starting School, UAE, UK, Downs Syndrome, SEN.

\section{Declarations}

Funding: None

Conflicts of interest: None

Availability of data/material: Not applicable

Code availability: Not applicable

During their early lifetimes, children will make multiple transitions between home and playgroup or nursery, between home and nursery, between different rooms or classes at nursery, and between classes and year groups at school. The transition which has the most lasting effect however can be argued to be the transition into compulsory full-time schooling. This transition should be seen as a period of adjustment to change, rather than a single point in time, beginning before entry into school and continuing throughout the Reception year. Transitions involve a range of changes (Rimm-Kaufman \& Pianta, 2000) including changes in social networks, in child-teacher ratios, in behavioural expectations and in environment (Walker et al., 
2012). For children with previous EYFS or nursery experience, particularly if it is in the same school, the transition may be easier. Some children also need longer to settle in and make the transition successfully (Kinkead-Clark, 2015).

"Each of these (transition) experiences is likely to affect children and their capacity to adjust and learn. Such is the significance of early transitions for young children that it is essential that parents, educators, policy makers and politicians pay close attention to young children's experiences in order to provide well for them" (Fabian \& Dunlop, 2002, p87).

Cross-cultural research on transitions to full time compulsory schooling argues that these experiences are related to subsequent social competence and academic achievement (Tizard et al., 1988; Ramey \& Campbell, 1991). The importance of the transition experience to children's physical, emotional and intellectual development has also been highlighted (Yeboah, 2002). O'Sullivan and Ring (2018) argue that early years education is becoming more 'schoolified' with pressure to move away from a 'playful pedagogical approach' to more formal approaches to teaching and learning in readiness for the later school years. The transition to compulsory schooling is usually the point where education and expectations become more formal. There is a sensitive period for later academic and social success in the transition to school and more formal learning (Rimm-Kaufman \& Pianta, 2002, p.494). A recent review of studies of children's biological stress response (Parent et al., 2019) as measured by cortisol levels argues that the transition from pre-school to school can result in elevated stress hormone levels for up to six months. Children then may find the transition very stressful, particularly if they are more shy or fearful in temperament. There is some suggestion that the quality of the teacher-child relationship may moderate this biological response (Parent et al. 2019).

Unlike School Readiness which focuses on the individual child's response to entering school, transition occurs over time and focuses on the child and their network of relationships. Griebel and Neisel (2009) identify changes and development at three levels during transition: the individual (for the child and parents), interactive (changes in roles and relationships for the child and family) and 
contextual (changes in learning environment, curriculum, travel, lines of communication between home and educational institution); these can be seen to have been negotiated successfully if the child has a sense of well-being and copes with the requirements of school. Rimm-Kaufman and Pianta (2000) developed a theoretical framework for transition, the Ecological and Dynamic Model of transition. Within this model, transition affects more than just the child entering school. We should see children as part of a family, all of whom contribute to the transition experience and are affected by it, together with staff and children at the school, and others in the wider family and community. Children and families are negotiating changes in many areas, such as the change in the format and expectations of the learning environment, often from home based or more informal pre-school settings to a more structured formal learning environment (Fabian, 2002); changes in children's views of themselves and their identity (Pianta \& Cox, 1999); and practical changes such as the logistics of transportation and organization in readiness for school and the challenge of adapting to a whole day in the educational environment. Yeboah (2002) identifies several factors affecting successful transition to school, including those associated with the school, the home, the child, learning in different settings, and the language and culture of the home versus that of the school. The success of the transition experience then does not rest solely on the child and their readiness for school, but also on how well prepared and adaptable the adults and contexts in their life are.

Previous research has found similarities, but also differences in parents' and teachers' expectations around the transition to school. Lewit and Baker (1995) found that parents value academic performance more highly than teachers do, whereas teachers focus much more on the need for children to be healthy and physically well to facilitate the transition. Parents' concerns are focused on several areas such as how well their child will settle into the group and adjust to the new setting, whether they will make friends, and whether they will have the knowledge they need. This emphasis by parents but not teachers on academic skills is echoed by Dockett \& Perry (2004) and Frederickson et al. (2004). Parental confidence about transition is related to better social adjustment by their children (Giallo et al., 2008). More recent research (Chan, 2011) in Hong Kong however found pre-academic skills are rated differently by each interest group. Kindergarten teachers see them as least important 
for transition, whereas they are seen as most important by parents and primary school teachers: the opinions of parents and primary teachers are closer to each other than those of pre-school staff. In Portugal (Correia \& Marques-Pinto, 2016), differences were found between teacher and parent expectations: preschool and primary teachers agreed in ranking family factors (such as parental involvement and support) as important to transition to school, whereas parents thought the teachers' characteristics and how the school was managed were more important. This suggests that both parents and teachers rate each other as important to successful transition. There are also differences in parental and teacher views depending on the country and culture.

Preschool children with Special Educational Needs (SEN) often find the transition to school more of a challenge than others do (Janus et al., 2008), with success depending on how well the child is able to adapt to the new setting and on how well parents, teachers and the school support the child's learning. They are often perceived as less ready for school (Dockett \& Perry, 2013). Outcomes, whether academic, social, emotional or behavioural, are more likely to be negative for these children (Baker et al., 2006). Parents are important in providing information about their children whilst teacher attitudes, expectations and interaction with parents and other relevant people are key in ensuring the transition is effective and successful (Salend, 2008). There is evidence that parents of children with SEN worry more than the parents of other children (Brandes, 2007) about the transition into formal education. Children with SEN are less likely to attend early years care settings with the children they may be entering a mainstream classroom with (Gilley et al., 2015) which affects social adjustment once in school. For these children and families, transdisciplinary networks to support transition are valuable (Krakouer et al., 2017) as well as a focus on partnerships and in-service training for all staff in both preschool and school settings.

Teachers' perspectives, expectations and attitudes are important factors in transition planning for all children, but especially for children with special needs (Dukmak, 2013; Elhoweris \& Sheikh, 2006). Previous research shows that teachers' attitudes towards children with SEN affects the success of the move into the Early Years Foundation Stage (Haines, Fowler \& Chandler, 1988), with teacher information and 
experience with children with similar needs creating more positive expectations about inclusion (Avramidis et al., 2000), especially for children with Down syndrome (Campbell et al., 2003). Takriti, Elhoweris and Atkinson (2018) argued that teachers in the UAE show a different pattern of expectations for children with Downs Syndrome and for children with no SEN. Teachers perceive barriers to inclusion to include the level of support available from school administration and in resourcing, as well as the quality and availability of preservice and in-service training (Leatherman \& Niemeyer, 2005). A study of teachers in Scotland revealed that many feel uneasy about inclusion (Florian, 2012) due to a perceived lack of specific expertise. Research with Greek teachers revealed similar findings (Zoniou-Sideri \& Vlcahou, 2006), whereas there is evidence that in the UAE, teachers may be more positive about inclusion for children with physical rather than intellectual SEN (Algazo \& Gaad, 2004). Teachers may also fear that inclusion will increase their workload (Alasim \& Paul, 2018; Gaad \& Khan, 2007) because children with SEN may need additional adaptations and differentiation in the curriculum or individual lessons. Teachers may feel negatively about inclusion because they are unsure how to adapt the curriculum appropriately (Lopes, Monteiro \& Sil, 2004). Australian research (Walker et al., 2012) suggests that teachers have difficulty managing noncompliant behaviour from children with SEN, and also identify difficulties for some children with SEN in organizing their belongings, paying attention and working independently. Walker et al. (2012) also found that classroom resources could be an issue in including children with SEN.

Teacher perceptions of children and expectations about their academic potential are also important to children's transition to school and their level of achievement there. Research illustrates that children respond to their teacher's expectations (RubieDavies, 2010; Boehlert, 2005; Good \& Brophy, 1994). Teacher attitudes are related to perceived levels of support by pupils and parents, and these also affect their management of the classroom learning environment - when they are more positive, pupils reported being more satisfied and feeling greater cohesion (Monsen et al., 2014). Therefore, if teachers have more positive expectations for children with SEN, their level of achievement is likely to be higher. 
Transition to school research has largely been conducted in America (Rosenkoetter \& Rosenkoetter, 1983), the UK (Katz, 2010; Peters \& Dunlop, 2014) and Australia (Dockett \& Perry, 2004). Britto \& Limlingan (2012) stress the importance of conducting research on starting school cross-culturally in their publication for UNICEF.

Teacher expectations and attitudes then can influence the kind of activities and pretransition preparation programmes for children both with and without SEN. It is therefore very useful to investigate these in order to enhance the transition experience as much as possible for all children and improve outcomes. This paper compares Early Years Foundation Stage teacher expectations for children with Down Syndrome and normally developing children across two cultures: in UK mainstream schools and in private schools in the UAE. This research study therefore aims to see whether EYFS teachers in England and the UAE share similar expectations for children starting school. Down Syndrome was selected as a specific SEN to focus on due to the change in the law in the UAE, and also because it is less familiar to teachers in the UK than some other conditions such as autism and ADHD. This paper therefore examines whether there are differences in teacher expectations for children starting school according to where the teacher is located and whether the child has Downs Syndrome or not.

The inclusion of children with SEN is a legal requirement in England \& Wales: "The UK government in committed to inclusive education of disabled children and young people and the progressive removal of barriers to learning and participation in mainstream education". (DfE, 2015). The Equality Act (2010) states that schools cannot lawfully discriminate against children on the basis of disability. Schools must have a qualified, designated Special Educational Needs Coordinator (SENCo) and a transparent SEN policy (DfE, 2015). The National Curriculum (DfE, 2014) and Teacher Standards give teachers the responsibility for ensuring an inclusive curriculum is delivered and that all children make progress. In the UAE, 'expats' from other countries far outnumber UAE nationals. The children of foreign nationals are educated in fee paying, private schools and taught by foreign national teachers. UAE nationals can choose free government schools or go to the expat private schools. Both school systems are covered by UAE legislation about inclusion. 
A Federal Law in 2006 (no.29, Article 12) granted children with SEN the right to education in general education classrooms (Federal Law 29/2006). The Abu Dhabi Department of Education and Knowledge (ADEK) and Zayed Higher Organization for Humanitarian Care signed an agreement to integrate children with SEN into general education classrooms. As a result, the numbers of children with mild and moderate SEN being enrolled in inclusive Early Years programmes has increased rapidly, with some level of resistance from parents.

\section{Method:}

\section{Design}

An independent groups repeated measures design was utilized. Two groups of Early Years Practitioners took part: the first group was living and working in the UAE and the other was living and working in the UK. The participants completed a 20 item questionnaire designed by Dockett \& Perry (2004), thinking about their expectations for children with Down Syndrome and for children with no SEN as they start school.

\section{Participants}

90 teachers working in Early Years' settings were recruited for the study. All participants were teachers working in the Early Years Foundation Stages (EYFS) in schools or nurseries in the UAE or UK. There were 50 teachers living and working in the UAE, teaching in EYFS in private schools; and 40 teachers living and working in England and teaching in the EYFS in state schools. The UAE teachers were foreign nationals who had undergone teacher training in the UK. Personal data was not collected to preserve anonymity. Social media and word of mouth were used to recruit participants. Teaching experience ranged from 1 year to 27 years, with a mean of 10.21 years (standard deviation 6.26). 


\section{Materials}

The questionnaire was available via a link to a Google form and was completed on line. Participants were asked to rate 20 items for how important each was in deciding how successful a child's first two terms at school were. They completed the questionnaire twice, once considering teaching children with Down Syndrome and once considering children with no SEN. A 4 point Likert scale (Not Important, Somewhat Important, Very Important, Extremely Important) was employed for each item. This questionnaire was taken from Dockett and Perry (2004).

Online participation via Google forms was employed to guarantee anonymity and confidentiality. Demographic information provided included how many years participants had been working in Early Years' education and which country they were currently living and working in.

\section{Procedure:}

Ethical approval was sought from the University of UAE and the Carnegie School of Education at Leeds Beckett University. Participants accessed the survey online and completed it in their own time. The survey took about10 minutes to complete.

\section{Results}

The responses to the 20 items on the questionnaire were grouped according to 6 scales following reliability analysis: knowledge (ability to count, read or write), adjustment (making friends at school, parents and teachers pleased with their social adjustment), family (parents are happy to leave the child at school, the child separates easily from them), disposition (the child's feelings about going to school and talking to the teacher), expectations (following school routines) and academic (child, teacher and parents are positive about the child's academic progress). Table 1 shows the means and standard deviations for the 6 scales which were answered in 
relation to children with Downs Syndrome or those with no SEN. The table displays these means separately for respondents from the UAE, those from the UK and for the sample as a whole.

\begin{tabular}{|c|c|c|c|c|}
\hline Scale & $\begin{array}{l}\text { No SEN/ Downs } \\
\text { Syndrome }\end{array}$ & UAE & UK & $\begin{array}{l}\text { Whole } \\
\text { Sample }\end{array}$ \\
\hline \multirow[t]{2}{*}{ Knowledge } & No SEN & $2.23(0.54)$ & $1.82(0.50)$ & $2.04(0.57)$ \\
\hline & DS & $1.62(0.51)$ & $1.68(0.44)$ & $1.65(0.48)$ \\
\hline \multirow[t]{2}{*}{ Adjustment } & No SEN & $2.59(0.49)$ & $2.65(0.68)$ & $2.64(0.61)$ \\
\hline & DS & $2.80(0.62)$ & $3.00(0.68)$ & $2.88(0.65)$ \\
\hline \multirow[t]{2}{*}{ Family } & No SEN & $2.40(0.43)$ & $2.49(0.54)$ & $2.44(0.48)$ \\
\hline & DS & $2.15(0.55)$ & $2.43(0.53)$ & $2.27(0.55)$ \\
\hline \multirow[t]{2}{*}{ Disposition } & No SEN & $2.97(0.57)$ & $3.39(0.45)$ & $3.16(0.56)$ \\
\hline & DS & $3.03(0.58)$ & $3.48(0.49)$ & $3.23(0.58)$ \\
\hline \multirow[t]{2}{*}{ Expectations } & No SEN & $2.67(0.38)$ & $2.20(0.61)$ & $2.46(0.55)$ \\
\hline & DS & $2.45(0.51)$ & $2.09(0.64)$ & $2.29(0.59)$ \\
\hline \multirow[t]{2}{*}{ Academic } & No SEN & $2.75(0.41)$ & $2.76(0.39)$ & $2.76(0.39)$ \\
\hline & DS & $2.51(0.56)$ & $2.77(0.45)$ & $2.63(0.53)$ \\
\hline
\end{tabular}

Table 1: Means and Standard Deviations on the 6 scales split by UAE and UK teachers and for the sample as a whole.

For each of the scales in turn, a repeated measures ANOVA was used to look for differences relating to whether the respondent was working in the UAE or UK (location) and/or according to whether they were answering in relation to children with Downs Syndrome or with no SEN.

Knowledge

An effect of SEN was obtained $(F(1,88)=30.97, p<0.001)$. This indicated that scores on the knowledge scale were higher for children with no SEN than for children with Downs Syndrome.

An interaction effect between location and condition was obtained $(F(1,88)=12.54$, $\mathrm{p}<0.001)$. Post-hoc t-tests revealed a significant difference for children with no SEN 
according to location $(t=3.71, d f=80, p<0.001)$. Expectations for Knowledge were higher for children with no SEN in the UAE than in the UK. There was no such difference for children with Downs Syndrome between the two locations.

No further main or interaction effects were obtained.

\section{Adjustment}

An effect of SEN was obtained $(F(1,88)=6.93, p<0.001)$. This indicated that scores on the adjustment scale were higher for children with Downs Syndrome than for children with no SEN.

No further main or interaction effects were obtained.

\section{Family}

An effect of SEN was obtained $(F(1,88)=7.58, p<0.001)$. This indicated that scores on the family scale were higher for children with no SEN than for children with Downs Syndrome.

No further main or interaction effects were obtained.

\section{Disposition}

An effect of SEN was obtained $(F(1,88)=4.70, p<0.005)$. This indicated that scores on the disposition scale were higher for children with Downs Syndrome than for those with no SEN.

No further main or interaction effects were obtained.

\section{Expectations}

An effect of SEN was obtained $(F(1,88)=6.45, p<0.01)$. This indicated that scores on the expectation scale were higher for children with no SEN than for children with Downs Syndrome.

No further main or interaction effects were obtained. 
An effect of SEN was obtained $(F(1,88)=4.39$, $p<0.05)$. This indicated that scores on the Academic scale were higher for children with no SEN than for children with Downs Syndrome.

An interaction effect between location and condition was obtained $(F(1,88)=5.05$, $p<0.05)$. Post-hoc t-tests revealed a significant difference for children with Downs Syndrome according to location $(t=2.40, d f=89, p<0.01)$. Scores on the Academic scale were higher for children with Downs Syndrome in the UK than in the UAE. There was no such difference for children without SEN between the two locations. No further main or interaction effects were obtained.

\section{Discussion}

The findings show a pattern of similarities and differences between teachers in the two countries for children with Down syndrome and those without. Means on the subscales for each country and for children with or without SEN indicate that, in both countries for all children, Disposition is ranked highest and Knowledge lowest. In both the UAE and UK, 'academic' is seen as the second most important factor for children without SEN; in both countries, Adjustment and Academic are rated as second and third most important for children with Down Syndrome. In England, Family and Expectations are rated $4^{\text {th }}$ and $5^{\text {th }}$ most important for both groups of children; Family is rated $5^{\text {th }}$ for both sets of children in the UAE.

Statistical analyses show that the Knowledge, Family, Expectations and Academic scales are rated as significantly more important for children with no SEN in both countries. This suggests that teachers see these factors as less important or less attainable for children with Down Syndrome. Scores on the Adjustment and Disposition scales were significantly higher for children with Down Syndrome than for those without SEN. Teachers in both countries therefore see these aspects (being happy to go to school and separate from carers, being able to form relationships and make friends with peers) as more important for children with Down Syndrome in making a successful transition to school, perhaps because knowledge and academic 
aspects are seen as easier to teach if the child is settled and conforming to classroom routines.

The analyses revealed two significant interactions: Knowledge expectations were significantly higher for children with no SEN in the UAE. This suggests early academic skills such as being able to count, recognise letters or words and write them is considered more important to a successful transition in the UAE for children without SEN. This could reflect differences between the two countries in academic expectations in the EYFS stage of schooling. The 'Academic' scale was rated significantly higher for children with Down Syndrome in the UK, which may reflect greater knowledge about the condition there or greater experience of working with children with SEN in the EYFS in English schools. It is important to note though that the 'academic' scale refers to the teacher and parents being positive about the child's academic progress: this does not necessarily imply that they are expected to make as much progress as other children but that their progress should be sufficient to meet expectations.

A potentially salient point to highlight is that all the teachers who took part in the survey worked in schools using the English National Curriculum and were trained in the UK. Despite this, expectations differ in key areas. For example, there are lower expectations for children with Down Syndrome in terms of Knowledge, Family, Expectations and Academic. This could be significant in terms of outcomes for these children if they are living up to teacher expectations (Takriti et al., 2018; Boehlert, 2005). Children with SEN may well need support and adjustments, but if expectations are lower than for children without SEN, then any gaps between them on attainment at school entry are likely to widen. The research literature highlights the effects of primary school ability grouping, and 'segregated inclusion', where children with SEN are physically present in the mainstream school but are always working in a separate group and often out of the classroom with a teaching assistant (Florian \& Black-Hawkins, 2011; Webster et al., 2010).

There are higher expectations shown for children with Down Syndrome in Adjustment and Disposition. This may indicate that teachers see these factors as important as they indicate the child will fit into the classroom without too many 
behaviour issues. Perhaps they feel Academic needs can be addressed provided the child can manage being with other children and integrate successfully into existing classroom routines. This supports findings from previous studies that teachers are concerned about managing behaviour of children with SEN (Walker et al., 2012): concerns around differentiation and resourcing may reduce if the child fits in with classroom routines and expectations (Alasim \& Paul, 2018; Gaad \& Khan, 2007).

The statistically significant interactions may reflect differences in the education systems. Knowledge may be seen as more important in the UAE for those without SEN, whereas Academic is more important in the UK for all children including those with SEN. This may reflect the demands of the National Curriculum which is now affecting the EYFS curriculum and pedagogy in terms of baseline screening, preparation for the Year 1 phonics test and increasing 'datafication' of children (Pierlejewski, 2019). This difference in expectation however is concerning in the light of research on the importance of teacher expectations to pupil attainment (RubieDavies, 2010; Boehlert, 2005; Good \& Brophy, 1994): if teachers expect less academically from children with SEN, then these children are likely to achieve less.

Dockett and Perry (2004) found that teachers in Australia focused on Adjustment, Family and Disposition for a successful start to school. This is supported here in terms of adjustment and disposition for SEN, as are Lin, Lawrence \& Gorrel's findings (2003) on the importance of social skills for children with SEN. This may also reflect teachers' concerns about compliance and behaviour when including children with SEN (Walker et al., 2012).

Family (ease of separation), Disposition (being happy to go to school) and Academic (family, teachers and children being happy with progress) are rated as more important by teachers in England for children with SEN. This suggests a more social approach with a higher focus on family/school partnership. Expectation (knowing school routines) was more important for UAE teachers.

Implications of the findings from this study are that it is important to raise expectations for children with SEN and to highlight the importance of being aware of all children's strengths and areas for improvement. Transition to school should be 
seen as occurring over a period of time rather than just as a one-off moment on the first day of school. Policies and practices which enable the child, family and school to get to know each other and share information are beneficial in easing this transition and ensuring a positive beginning to the journey through the education system.

Limitations within the study include the focus on teachers alone. Children are part of a complex social network including their family, friends and community as well as the school and teachers, so understanding the transition process means we need to include all the stakeholders involved in and affected by the transition to school. It would also be interesting to know whether similar expectations are held for other children with SEN or whether those with Down Syndrome are a special case.

Qualitative data in addition to the survey data would also add richness and depth.

\section{References:}

Alasim, K. \& Paul, P.V. (2018). Understanding factors that affect teachers' attitudes towards inlusion of students who are hard of hearing in Saudi Arabia. Deafness \& Education International, DOI: 10.1080/14643154.2018.1489950

Alghazo, E.M. \& Gaad, E. (2004). General education teachers in the United Arab Emirates and their acceptance of the inclusion of students with disabilities. British Journal of Special Education, 31, 2, 94-99.

Avramidis, E., Bayliss, P. \& Burden, R. (2000). Student teachers' attitudes towards the inclusion of children with special educational needs in the ordinary school. Teaching and Teacher Education, 16, 3, 277-293.

Baker, B.L., Blacher, J. \& Mclntyre, L.L. (2006). The transition to school: Adaptation in young children with and without intellectual disability. Journal of Intellectual Disability Research, 50, 5, 349-361.

Boehlert, M. (2005). Self-fulfilling prophecy. In S.W. Lee (Ed.), Encyclopedia of School Psychology (pp 491-492). Thousand Oaks, CA: Sage. 
Brandes, J.A., Ormsbee, C.K. \& Haring, K.A. (2007). From early intervention to early childhood programs: Timeline for early Succesful Transitions (TEST). Intervention in School and Clinic, 42, 4, 204-211.

Britto, P.R. \& Limlingan, M.C. (2012). School Readiness and Transitions. New York: UNICEF.

Campbell, J., Gilmore, L. \& Cuskelly, M. (2003). Changing student teachers' attitudes towards disability and inclusion. Journal of Intellectual \& Developmental Disability, 28, 4, 369-379.

Chan, W.L. (2012). Expectations for the transition from kindergarten to primary school amongst teachers, parents and children. Early Child Development and Care, $182,5,639-664$.

Correia, K. \& Marques-Pinto, A. (2016). Adaptation in the transition to school: perspectives of parents, preschool and primary teachers. Educational Research, 58, 3, 247-264.

Department for Education (2014). The National Curriculum in England: complete framework for key stages 1 to 4 . Available at:

https://www.gov.uk/government/publications/national-curriculum-in-englandframework-for-key-stages-1-to-4 (Accessed: 11 November 2019).

Department for Education and Department of Health (2015). Special educational needs and disability code of practice: 0 to 25 years. Available at:

https://www.gov.uk/government/publications/send-code-of-practice-0-to-25 (Accessed: 11 November 2019).

Equality Act (2010). London: The Stationery Office.

Dockett, S. \& Perry, B. (2004). What makes a successful transition to school? Views of Australian parents and teachers. International Journal of Early Years Education, 12, 3, 217-230. 
Dockett, S. \& Perry, B. (2013). Trends and tensions: Australian and International research about starting school. International Journal of Early Years Education, 21: 23, 163-177.

Dukmak, S.A. (2013). Regular classroom teachers' attitudes towards including students with disabilities in the regular classroom in the United Arab Emirates. The Journal of Human Resource and Adult Learning, 9 (1), 26-39.

Elhoweris, H. \& Alsheikh, N. (2006). Teachers' attitude toward inclusion. International Journal of Special Education, 21,1, 115-118.

Fabian, H. (2002). Children Starting School: A guide to successful transitions and transfers for teachers and assistants. London: Routledge.

Fabian, H. \& Dunlop, A-W. (2002). Introduction, in H. Fabian \&a-W Dunlop (Eds) Transition in the Early Years: debating continuity and progression for young children in early education. London: Routledge Falmer

Florian, L. (2012). Preparing teachers to work in inclusive classrooms. Journal of Teacher Education, 63, 4, 275-285.

Florian, L. \& Black-Hawkins, K. (2011). Exploring inclusive pedagogy. British Educational Research Journal, 37,5, 813-828.

Gaad, E. \& Khan, L. (2007). Primary mainstream teachers' attitudes towards inclusion of students with special educational needs in the private sector: $A$ perspective from Dubai. International Journal of Special Education, 22, 2, 95-109.

Griebel, W. \& Niesel, R. (2009). A developmental psychology perspective in Germany: co-construction of transitions between family and education system by the child, parents and pedagogues. Early Years, 29:1, 59-68. 
Hains, A.H., Fowler, S.A. \& Chandler, L.K. (1988). Planning school transitions: Family and professional collaboration. Journal of the Division for Early Childhood, $12,2,108-115$.

Federal Law No. 29/2006. (2006). On the rights of persons with special needs. United Arab Emirates.

Frederickson, N., Dunsmuir, S., Lang, J. \& Monsen, J.J. (2004). Mainstream-special school inclusion partnerships: Pupil, parent and teacher perspectives. International Journal of Inclusive Education, 8, 1, 37-57.

Giallo, R., Treyvaud, K., Matthews, J. \& Kienhuis, M. (2010). Making the transition to primary school: An evaluation of a transition programme for parents. Australian Journal of Educational and Developmental Psychology, 10, 1-17.

Gilley, T., Niklas, F., Tayler, C. \& Cloney, D. (2015). Too late and not enough for some children: early childhood education and care (ECEC) program usage patterns in the years before school in Australia. International Journal of Child Care and Education Policy, 9, 1,

Good, T.L. \& Brophy, J.E. (1994). Looking in Classrooms (6 $6^{\text {th }}$ ed.). New York, NY: Harper \& Row.

Griebel, W. \& Neisel, R. (2009). A developmental psychology perspective in Germany: Co-construction of transitions between family and education system by the child, parents and pedagogues. Early Years: An International Research Journal, 29, 1, 59-68.

Janus, M., Kopechanski, L., Cameron, R. \& Hughes, D. (2008). In transition: Experiences of parents of children with special needs at school entry. Early Childhood Education Journal, 35, 479-485.

Katz, L. (2010). STEM in the early years. Early Childhood Research and Practice, $27,1,225-237$. 
Kinkead-Clark, Z. (2015). 'Ready for big school': making the transition to primary school - a Jamaican perspective. International Journal of Early Years Education, 23, $1,67-82$.

Krakouer, J., Mitchell, P. \& Trevitt, J. (2017). Early Years Transitions: Supporting children and families at risk of experiencing vulnerability - rapid literature review. East Melbourne: State of Victoria (Department of Education and Training).

Leatherman, J.M. \& Niemeyer, J.A. (2005). Teachers' attitudes towards inclusion: Factors influencing classroom practice. Journal of Early Childhood Teacher Education, 26, 23-36

Lewit, E.M. \& Baker, L.S. (1995). School Readiness. The Future of Children, 5, 2, 128-139.

Lopes, J.A., Monteiro, I. \& Sil, V. (2004). Teachers' perceptions about teaching problem students in regular classrooms. Education and Treatment of Children, 27, 4, 394-419.

Monsen, J.J., Ewing, D. \& Kwoka, M. (2014). Teachers' attitudes towards inclusion, perceived adequacy of support and classroom learning environment. Learning Environments Research, 17, 1, 113-126.

O'Sullivan, L. \& Ring, E. (2018). Play as learning: implications for educators and parents from findings of a national evaluation of school readiness in Ireland. International Journal of Play, 7, 3, 266-289.

Parent, S., Lupien, S., Herba, C.M., Dupere, V., Gunnar, M.R. \& Seguin, J.R. (2019). Children's cortisol response to the transition from preschool to formal schooling: a review. Psychoneuroendocrinology, 99, 196-205.

Peters, S. \& Dunlop, A-W. (2014). Editorial. Early Years, 34, 4, 323-328. 
Pianta, R.C. \& Cox, M. (Eds) (1999). The transition to kindergarten. Baltimore: Paul H Brookes.

Pianta, R.C., Cox, M.J., Taylor, L. \& Early, D. (1999). Kindergarten Teachers' practices related to the transition to school: Results of a national survey. The Elementary School Journal, 100, 1, 71-86.

Pierlejewski, M. (2019). The data-doppelganger and the cyborg-self: theorising the datafication of education. Pedagogy, Culture \& Society, DOI:

10.1080/14681366.2019.1653357

Ramey, C.T. \& Campbell, F.A. (1991). Poverty, early childhood education and academic competence: The abecedarian experiment. In A.C. Huston (Ed.), Children in Poverty: Child development and public policy (pp 180-221). New York NY: Cambridge.

Rimm-Kaufman, S. \& Pianta, R. C. (2000). An ecological perspective on the transition to kindergarten: A theoretical framework to guide empirical research. Journal of Applied Developmental Psychology, 21, 5, 491-511.

Rubie-Davies, C.M. (2010). Teacher expectations and perceptions of student attributes: Is there a relationship? British Journal of Educational Psychology, 80, $121-135$

Salend, S.J. (2008). Creating inclusive classrooms: Effective and reflective practices. New York: Prentice.

Takriti, R.A., Elhoweris, H. \& Atkinson, S.J. (2018). Examining the expectations of early years' teachers in the UAE regarding a successful start to school for children with and without special educational needs. Early Child Development and Care, DOI: $10.1080 / 03004430.2018 .1480144$ 
Takriti, R.A., Elhoweris, H. \& Atkinson, S.J. (2018). Teachers' expectations of what makes a successful start to school for children with Downs Syndrome: A crosscultural comparison of the UAE and the UK. European Journal of Special Needs Education, 34:4, 546-554, DOI: 10.1080/08856257.2018.1553137

Tizard, B., Blatchford, P., Burke, J., Farquhar, C. \& Plewis, I.(1988). Young children at school in the inner city. London: Erlbaum.

Walker, S., Dunbar, S., Meldrum, K., Whiteford, C., Carrington, S., Hand, K., Berthelsen, D. \& Nicholson, J. (2012). The transition to school of children with developmental disabilities: Views of parents and teachers. Australasian Journal of Early Childhood, 37, 3, 22-29.

Webster, R., Blatchford, P., Bassett, P., Brown, P., Martin, C. \& Russell, A. (2010). Double standards and first principles: framing teacher assistant support for pupils with special educational needs. European Journal of Special Needs Education 25, 4, 319-336.

Yeboah, D.A. (2002). Enhancing transition from Early Childhood Phase to Primary Education: Evidence from the research literature. Early Years: An International Journal of Research and Development, 22, 1, 51-68.

Zoniou-Sideri, A. \& Vlachou, A. (2006). Greek teachers' belief systems about disability and inclusive education. International journal of Inclusive Education, 10, 45, 379-394. 